\title{
KECEMASAN TOKOH UTAMA WANITA PADA FILM MANUK KARYA GHALIF PUTRA SADEWA
}

\author{
Aynul Iyzah dan Ridlwan \\ Pendidikan Bahasa dan Sastra Indonesia, Universitas Muhammadiyah Surabaya \\ aynuliyzah95@gmail.com
}

\begin{abstract}
ABSTRAK
Tujuan dari penelitian ini adalah mendeskripsikan tentang kecemasan pada tokoh utama wanita dalam film manuk karya Ghalif Putra sadewa. Penelitian ini menggunakan metode penelitian kualitatif. Sumber data penelitian ini berasal dari film Manuk Karya Ghalif Putra sadewa yang ditonton melalui youtube. Cara dalam pengumpulan data ini adalah menggunanakan teknik triangulasi yaitu dokumentasi, dan wawancara. Cara dokumentasi yaitu dengan cara mengambil beberapa potongan adegan yang menunjukkan kecemasan yang dialami tokoh utama wanita, dan dengan cara wawancara dengan sutradara film Manuk. Simpulan dari penelitian ini menunjukkan bahwa ada satu kecemasan realitas, enam kecemasan neurotik, dan satu kecemasan moral. Selain itu juga terdapat aspek psikologis individu yaitu dua aspek psikologis id, aspek psikologis individu ego, dan satu aspek psikologis superego.
\end{abstract}

Kata Kunci: film manuk; kecemasan

\begin{abstract}
The purpose of this study was to describe the anxiety of the female main character in the film Manuk by Ghalif Putra Sadewa. This study used qualitative research methods. The source of this research data came from the film Manuk by Ghalif Putra Sadewa which was watched via youtube. The method in collecting data was using triangulation techniques, namely observation, documentation, and interviews. The way of observation was by observing the film Manuk and interpreting the film, and the documentation was by taking a few pieces of scenes that show the anxiety experienced by the female main character, and the last is by interviewing the film director of Manuk. The conclusion of this study indicated that there is one reality anxiety, six neurotic anxieties, and one moral anxiety. In addition, there are also psychological aspects of the individual namely two psychological aspects of the id, the psychological aspects of the individual ego, and one psychological aspect of the superego.
\end{abstract}

Keywords: manuk film; anxiety

\section{PENDAHULUAN}

Sastra adalah cerminan masyarakat yang berdampak pada munculnya sebuah karya sastra. Dalam kehidupan bermasyarakat sastra juga sangat dipengaruhi oleh 
tingkah laku maupun kebiasaan dari masyarakat tersebut. Karena itu, bisa dikatakan bahwa sastra adalah cerminan masyarakat atau kebiasaan yang ada di lingkungan masyarakat. Dalam sebuah karya sastra tentunya keadaan masyarakatlah yang menjadi sebuah inspirasi untuk membuat sebuah karya sastra. Sastrawan dipengaruhi dan memengaruhi masyarakat; seni tidak hanya meniru kehidupan, tetapi juga membentuknya. Banyak orang meniru gaya hidup tokoh-tokoh dunia rekaan (Wellek dan Werren, 2014:109).

Karya sastra tidak hanya cerminan masyarakat, tetapi bersifat penting dalam kehidupan, pendidikan, maupun dalam bidang keilmuan dan sosial. Karena itu, karya sastra mewakili dari setiap kejadian yang ada di masyarakat. Tingkah laku masyarakat juga berpengaruh pada setiap pembuatan karya sastra yang ada pada saat itu juga. Maka dari itu setiap karya sastra dianggap mampu menarik peminatnya karena fenomena-fenomena yang terjadi saat itu. Karya sastra juga dapat dijadikan media pembelajaran baik di sekolah dasar maupun yang sudah lanjutan.

Karya sastra memang banyak sekali jenisnya baik berupa puisi, prosa, drama, cerpen, dan lain-lain sebagainya. Film juga termasuk karya sastra yang sangat digemari oleh kalangan masyarakat dewasa ini. Selain memunculkan cerita-cerita yang sangat menarik, film juga dapat menyajikan sebuah tayangan yang dapat menghibur peminatnya.

Film tidak hanya menyajikan suatu cerita yang bersifat fiktif saja, tetapi juga cerita yang berkembang di masyarakat berdasarkan kisah nyata yang terjadi di tengah-tengah masyarakat. Film merupakan drama modern yang menggabungkan antara audio dan visual yang dikemas secara menarik agar penonton atau peminatnya merasakan cerita tersebut seperti nyata tanpa adanya unsur rekayasa atau dibuat-buat.

Banyak sekali jenis-jenis karya sastra yang ada saat ini, tetapi yang sangat populer saat ini adalah karya sastra tentang film. Hal itu dikarenakan film mampu membuat daya tarik tersendiri bagi para pencintanya yaitu dengan cara menyajikan suatu tontonan bagi mereka yang sangat suka dengan film. Selain itu sudut pandang yang terdapat dalam film bisa membuat penontonnya sangat tertarik. Karena disajikan secara audio visual, film dapat menarik minat penonton. Hal itu disebabkan dalam sekali melihat film tersebut penonton akan langsung memahami isi yang disampaikan tanpa harus membaca berulang-ulang. 
Hal tersebut sangat berbeda dengan karya sastra berbentuk tulisan. Contohnya adalah novel, cerpen, atau kumpulan puisi. Penikmat sastra harus membaca buku tersebut supaya mereka memahami isinya. Namun, terkadang pembaca harus membaca dua hingga tiga kali supaya isi dalam karya sastra tulis tersebut bisa dipahami. Hal itu sangat berbeda dengan film yang visualisasi adegannya tergambar sangat jelas.

Tema film pada saat ini sangat beragam dan tidak monoton. Hal ini tentu dapat dilihat dari pagelaran Festival Film Indonesia (FFI) atau Apresiasi Film Indonesia (AFI) yang banyak menyuguhkan film yang memiliki tema di luar pasaran yaitu film Siti, Istirahatlah Kata-Kata, Ziarah, Banda The Dark, Forgotten Trial, Isu LGBT, dan masih banyak lagi. Meskipun begitu, tema cinta, romantis, horor, bahkan juga komedi masih dan akan selalu ada.

Beberapa film komedi muncul dengan cara mengambil cerita lama atau membangunkan kembali ingatan masyarakat dengan tokoh dalam film seperti film Warkop DKI Reborn. Ada juga film baru dikemas komedi seperti film My Stupid Boss, Cek Toko Sebelah, dan Susah Sinyal. Tentu itu suguhan baru meskipun tidak benar-benar hal baru karena jika menengok lebih jauh ke belakang, tema-tema yang diangkat dengan ringan sudah ada film-film Benyamin Syueb dan masih banyak lagi. Memang mayoritas film tersebut laku di masyarakat, tetapi ada juga yang gagal.

Gagal tidaknya suatu film bisa dilihat dari jumlah penonton yang menyaksikan film tersebut. Namun, hal tersebut tidak bisa berlaku secara universal. Justru filmfilm yang bertema idealisme dan tidak berdasarkan kebutuhan pasar tampak lebih bagus secara naratif maupun tampilannya. Hal tersebut terlihat dari film Tengkorak yang lebih dari tiga tahun berproses dan akhirnya masuk dalam Fest Film di Amerika. Ada pula sosok Garin Nugroho dengan karya-karya besarnya yaitu Nyai dan Setan Jawa. Selain tiga film itu, terdapat film yang berjudul Manuk, sebuah film yang mengangkat tema realitas sosial dalam suatu rumah tangga.

Manuk merupakan sebuah karya berupa film dari sutradara Ghalif Putra Sadewa. Film ini diproduksi pada tahun 2015. Film tersebut menceritakan tentang keadaan rumah tangga yang memang jarang sekali diangkat oleh sutradara dalam dunia perfilman. Mayoritas sutradara mengangkat konflik yang ada di luar rumah. Film 
Manuk menceritakan tentang konflik yang ada di dalam rumah dan dialami oleh sang istri.

Cerita dalam film tersebut unik dan sangat menarik. Selain itu, film ini juga mendapatkan tiga belas penghargaan baik dari dalam negeri maupun dari luar negeri. Penghargaan tersebut di antaranya yaitu Special Mention Malang Film Festival 2015, Best Sound Tebas Award Yogyakarta 2015, World Cinema 3rd Chennai International Short Film Festival -Indian 2016, dan masih banyak lagi.

Film Manuk menceritakan tentang kehidupan suami istri. Mereka berada dalam suatu lingkungan perkampungan yang ada di Yogyakarta. Sang istri adalah seorang ibu rumah tangga yang mampu menangani semua pekerjaan rumah tangga dengan baik, sedangkan sang suami adalah seorang staf pemerintahan yang ada di Yogyakarta. Sang suami memiliki hobi memelihara burung. Hobi memelihara burung ini menjadikannya lupa dengan kewajibannya, yaitu sering terlambat ke kantor bahkan tidak memperhatikan istrinya. Hobi memelihara burung ini menjadikannya lupa dengan segala hal yang berkaitan dengan dirinya maupun dengan sang istri. Akhirnya, sang istri melakukan kebohongan yang besar agar sang suami kembali memperhatikan sang istri yang selama ini sering tidak dia perhatikan karena hobi tersebut.

Dalam sebuah karangan terdapat suatu sifat yang berbeda juga sangat menarik untuk diperbincangkan. Contohnya adalah kecemasan yang dialami oleh tokoh tersebut. Dalam sebuah film kecemasan juga merupakan keadaan yang sangat mendukung dalam seni peran sehingga memunculkan sebuah pandangan yang sangat menarik untuk disajikan. Hal itu dikarenakan konflik yang terjadi dalam sebuah kecemasan menimbulkan perdebatan yang menarik untuk ditonton maupun dikaji. Dengan adanya kecemasan maka penonton juga dapat masuk ke dalam cerita film tersebut.

Kecemasan adalah situasi apapun yang mengancam kenyamanan suatu organisme lalu diasumsikan bisa melahirkan suatu kondisi. Berbagai konflik dan bentuk frustrasi yang menghambat kemajuan individu untuk mencapai tujuan merupakan salah satu sumber kecemasan. Ancaman yang dimaksud dapat berupa ancaman fisik, psikis, dan berbagai tekanan yang mengakibatkan timbulnya kecemasan. Kondisi ini diikuti oleh perasaan yang tidak nyaman dan dicirikan dengan 
istilah khawatir, takut, tidak bahagia, yang dapat dirasakan melalui berbagai level (Hilgard dalam Minderop, 2011:28). Kecemasan sebagai dampak dari konflik yang menjadi bagian kehidupan yang tak terhindarkan dipandang sebagai komponen dinamika kepribadian yang utama. Kecemasan adalah fungsi ego untuk memperingatkan individu tentang kemungkinan datangnya suatu bahaya sehingga dapat disiapkan reaksi adaptif yang sesuai (Alwisol,2014:22).

Kecemasan dapat berawal dari sebuah lingkungan, misalnya di sebuah lingkungan tersebut seseorang merasa tidak nyaman atau kehadirannya dianggap mengancam maka dia akan mengalami kecemasan atau ketidaknyamanan yang dianggapnya dapat menganggu kelangsungan hidupnya. Jadi, lingkungan dapat memberi kepuasan maupun mengancam atau dengan kata lain, lingkungan mempunyai kekuatan untuk memberikan kepuasan dan mereduksi tegangan maupun menimbulkan sakit dan menignkatkan ketegangan; dapat menyenangkan maupun menganggu (Sumadi, 2016:138).

Setiap tokoh memiliki karakternya masing-masing. Di dalam sebuah karya sastra pasti ada karakter tokoh yang berbeda dan memiliki permasalahan masing masing. Contohnya adalah kecemasan. Kecemasan ini bisa diakibatkan oleh dirinya sendiri maupun orang lain. Memilih kecemasan sebagai bahan penelitian sebuah film agar dapat ditelusuri secara komprehensif suatu hal yang menjadi latar belakang timbulnya masalah-masalah psikologis dari masing-masing tokoh serta dapat pula dipahami proses dan akibat dari kondisi-kondisi yang mendorong pencerminan konsep-konsep pada para tokoh yang dimaksud (Minderop, 2011:98).

\section{METODE PENELITIAN}

Penelitian ini menggunakan penelitian kualitatif. Satori dan Komariah (2017:22) menjelaskan bahwa penelitian kualitatif adalah penelitian yang menekankan pada kualitas atau hal yang terpenting dari suatu barang atau jasa berupa kejadian/fenomena/gejala sosial. Makna di balik kejadian tersebut dapat dijadikan pelajaran berharga bagi suatu pengembangan konsep teori. Jadi, jenis penelitian kualitatif ini menekankan pada kejadian atau fenomena yang terjadi di masyarakat bukan melalui angka-angka. Penelitian kulitatif adalah penelitian yang bersifat 
deskriptif. Peneliti yang menggunakan desain penelitian tersebut memiliki tujuan untuk mengeksplorasi fenomena-fenomena yang terjadi dalam penelitian.

Menurut Sugiyono (2015:7) jenis penelitian kualitatif menggunakan metode naturalistik yaitu tempat alamiah dan tidak ada perlakuan. Dalam penelitian kualitatif instrumennya adalah orang atau human interest, yaitu peneliti. Untuk dapat menjadi instrumen, maka peneliti harus memiliki bekal teori dan wawasan yang luas, sehingga mampu bertanya, menganalisis, memotret, dan mengonstruksi situasi sosial yang diteliti lebih jelas dan bermakna.

Yang dimaksud dengan penelitian naturalistik dalam penelitian ini adalah peneliti melihat melalui media youtube adegan-adegan yang ada di dalam film Manuk karya Ghalif Putra Sadewa. Penelitian ini menekankan pada berbagai macam teori yang menunjukkan tentang kepribadian terutama pada kecemasan. Dengan menggunakan metode penelitian kualitatif ini maka peneliti dan dapat menemukan hasil dari berbagai macam teori tentang kepribadian. Peneliti memilih penelitian kualitatif karena kecemasan pada tokoh utama dalam film Manuk yang diteliti dideskripsikan berdasarkan jenis kecemasan tertentu yang dialami tokoh utama melalui berbagai macam teori dan hasil wawancara dengan sutradara film Manuk.

\section{PEMBAHASAN}

\section{Kecemasan Realitas}

Kecemasan realitas adalah rasa takut terhadap bahaya-bahaya nyata di dunia luar, misalnya ketakutan akan berada sendiri di jalan yang gelap dan sepi atau ancaman terhadap kejahatan yang berada di jalan. Hal itu bisa menimbulkan perasaan kecemasan realitas. Kecemasan realitas ini dapat dikatakan kecemasan yang paling pokok. Menurut Sigmund Freud dalam Suryabrata (2016:139) kecemasan atau ketakutan yang realistis atau takut terhadap bahaya-bahaya di dunia luar merupakan kedua kecemasan yang diasalkan dari kecemasan realitas. Berikut kecemasan realitas yang terdapat dalam film Manuk. 
Tabel 1. Kecemasan Realitas dalam Film Manuk

\begin{tabular}{|c|c|c|l|c|c|}
\hline No. & $\begin{array}{c}\text { Menit } \\
\text { Awal }\end{array}$ & $\begin{array}{c}\text { Menit } \\
\text { Akhir }\end{array}$ & \multicolumn{1}{|c|}{ Adegan } & $\begin{array}{c}\text { Jenis } \\
\text { Kecemasan }\end{array}$ & Kode \\
\hline 1 & $2: 28$ & $2: 42$ & $\begin{array}{l}\text { Tokoh utama wanita atau } \\
\text { sang istri yang biasa } \\
\text { dipanggil Sum sedang } \\
\text { berbelanja bersama } \\
\text { tetangganya. Setelah itu } \\
\text { datanglah seorang laki-laki } \\
\text { yang akan berbelanja } \\
\text { dikarenakan istrinya sedang } \\
\text { hamil. Terlihat tokoh utama } \\
\text { wanita mengalami } \\
\text { kecemasan atas pembicaraan } \\
\text { tetanggnya mengenai } \\
\text { kehamilan. }\end{array}$ & $\begin{array}{c}\text { Kecemasan } \\
\text { realitas }\end{array}$ & FM/2:28/2:42 \\
\hline
\end{tabular}

Kecemasan realitas dalam film Manuk dibuktikan pada menit 2:28 sampai menit 2:42 dengan adegan Tokoh utama wanita atau sang istri yang biasa dipanggil Sum sedang berbelanja bersama tetangganya. Setelah itu datanglah seorang laki-laki yang akan berbelanja dikarenakan istrinya sedang hamil. Terlihat tokoh utama wanita mengalami kecemasan atas pembicaraan tetanggnya mengenai kehamilan.

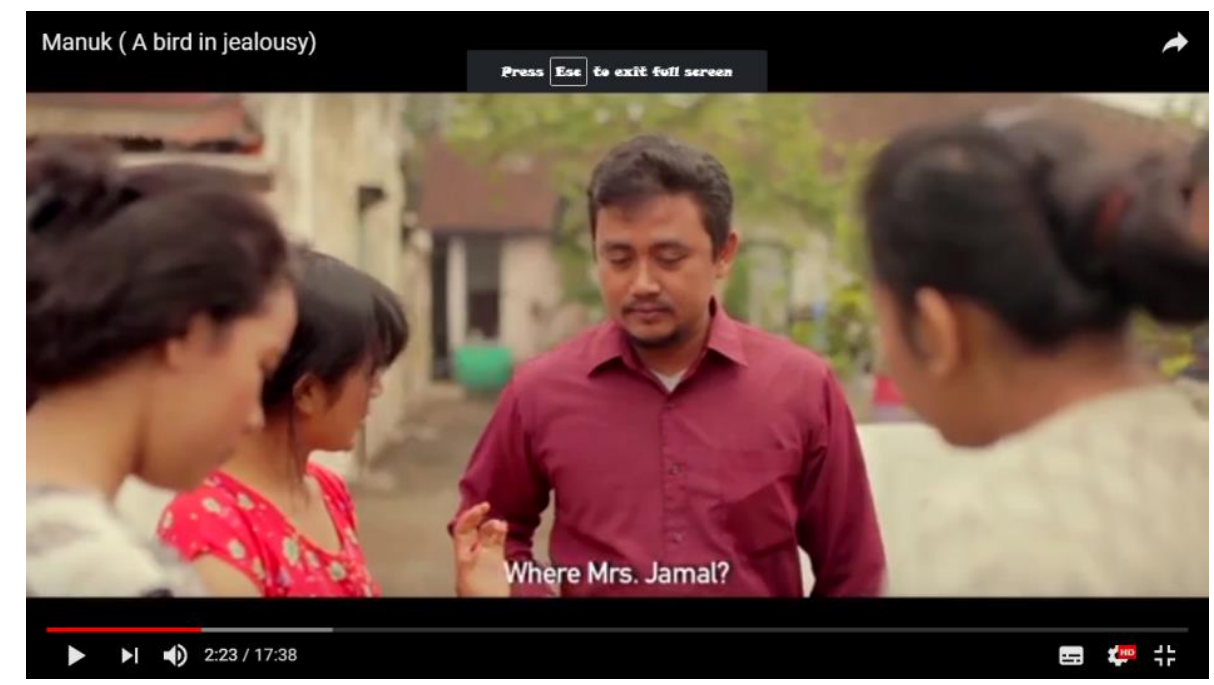

$(\mathrm{FM} / 2: 28 / 2: 42)$

Tokoh utama wanita pada adegan tersebut mengalami kecemasan realitas. Kecemasan realitas yaitu ketakutan terhadap dunia luar. Kecemasan yang dialami oleh tokoh utama dikarenakan tetangganya sedang membahas tentang kehamilan, sedangkan tokoh utama wanita ini tidak kunjung hamil. Menurut beberapa orang jika 
seorang wanita yang sudah bersuami dan tak kunjung hamil, dia akan mengalami ketakutan dikarenakan yang diinginkan wanita yang sudah menikah mayoritas yaitu kehamilan, sedangkan tokoh utama wanita ini tidak kunjung hamil. Di sisi lain semua tetangganya telah memiliki anak dan bahkan ada yang sedang hamil. Hal itu mengakibatkan tokoh utama wanita tersebut mengalami kecemasan realistis. Kecemasan realitas ini bisa dikatakan kecemasan yang sangat wajar dikarenakan kecemasan ini sering dialami dalam kehidupan sehari-hari. Namun, kecemasan realitas yang tidak segera ditangani akan menimbulkan kecemasan-kecemasan yang lain. Kecemasan tersebut nantinya akan menimbulkan frustrasi bahkan mengancam seseorang untuk melakukan tindakan yang di luar nalar.

Gangguan kecemasan realitas ini bisa disebabkan karena kekhawatiran yang berlebihan dan membuat seseorang mengalami gangguan atau depresi. Hal itu seperti yang telah dijelaskan sebelumnya yaitu tokoh utama wanita mengalami kecemasan dikarenakan tidak kunjung hamil. Di sisi lain beberapa tetangganya telah memiliki anak dan ada juga yang sedang hamil.

Menurut Sutradara Film Manuk yaitu Ghalif Putra Sadewa, beberapa orang yang sudah menikah, kehamilan merupakan karunia yang tidak ternilai dengan apapun. Jika seorang wanita sudah menikah dan tidak kunjung memiliki anak, wanita tersebut akan mengalami kecemasan yang dinamakan kecemasan realitas. Kecemasan realitas ini sangatlah wajar terjadi pada tokoh utama wanita dikarenakan kecemasan ini muncul ketika para tetangga mengatakan atau membahas tentang kehamilan

\section{Kecemasan Neurotik}

Kecemasan neurotik adalah rasa takut terhadap insting yang akan lepas dari kendali dan menyebabkan seseorang berbuat sesuatu yang bisa membuatnya dihukum. Kecemasan neurotik bukanlah ketakutan terhadap insting tersebut, melainkan ketakutan terhadap hukuman yang mungkin terjadi jika suatu insting dipuaskan. Kecemasan neurotik mempunyai dasar dalam kenyataan (Imam Malik, 2016:242). Berikut kecemasan neurotik yang terdapat dalam film Manuk. 
Tabel 2. Kecemasan Neurotik dalam Film Manuk

\begin{tabular}{|c|c|c|c|c|c|}
\hline No. & $\begin{array}{l}\text { Menit } \\
\text { Awal }\end{array}$ & $\begin{array}{l}\text { Menit } \\
\text { Akhir }\end{array}$ & Adegan & $\begin{array}{c}\text { Jenis } \\
\text { Kecemasan }\end{array}$ & Kode \\
\hline 1. & $1: 03$ & $1: 45$ & $\begin{array}{l}\text { Sang suami sedang merawat } \\
\text { burungnya dan lupa terhadap } \\
\text { waktunya untuk bekerja. } \\
\text { Sang istri mengingatkan } \\
\text { suami agar cepat berangkat } \\
\text { ke kantor dikarenakan sudah } \\
\text { siang, tetapi sang suami tetap } \\
\text { santai sembari bersiul dan } \\
\text { memerhatikan burung } \\
\text { peliharaanya. Akhirnya, istri } \\
\text { marah dan merasa bahwa } \\
\text { ucapannya tidak dihiraukan } \\
\text { karena suami lebih } \\
\text { memerhatikan burung } \\
\text { peliharaanya. }\end{array}$ & $\begin{array}{c}\text { Kecemasan } \\
\text { neurotik }\end{array}$ & FM/1:03/1:45 \\
\hline 2. & $2: 49$ & $3: 27$ & $\begin{array}{l}\text { Sang istri pulang dari } \\
\text { berbelanja, tetapi sang suami } \\
\text { tetap saja belum berangkat } \\
\text { ke kantor dan tetap merawat } \\
\text { burung peliharaanya dan } \\
\text { tidak menghiraukan istri. } \\
\text { Sang istri menoleh kepada } \\
\text { suami dan suaminya tetap } \\
\text { saja merawat burung } \\
\text { kesayangannya. Hal itu } \\
\text { berakibat pada sang istri } \\
\text { merasa dirinya tidak } \\
\text { diperhatikan oleh sang } \\
\text { suami. }\end{array}$ & $\begin{array}{c}\text { Kecemasan } \\
\text { neurotik }\end{array}$ & $\mathrm{FM} / 2: 49 / 3: 27$ \\
\hline
\end{tabular}

Kecemasan neurotik dalam film Manuk dibuktikan pada menit 1:03 sampai menit 1:45 dalam adegan sang suami sedang merawat burungnya dan lupa terhadap waktunya untuk bekerja. Sang istri mengingatkan suami agar cepat berangkat ke kantor dikarenakan sudah siang, tetapi sang suami tetap santai sembari bersiul dan memerhatikan burung peliharaanya. Akhirnya, istri marah dan merasa bahwa ucapannya tidak dihiraukan karena suami lebih memerhatikan burung peliharaanya. 


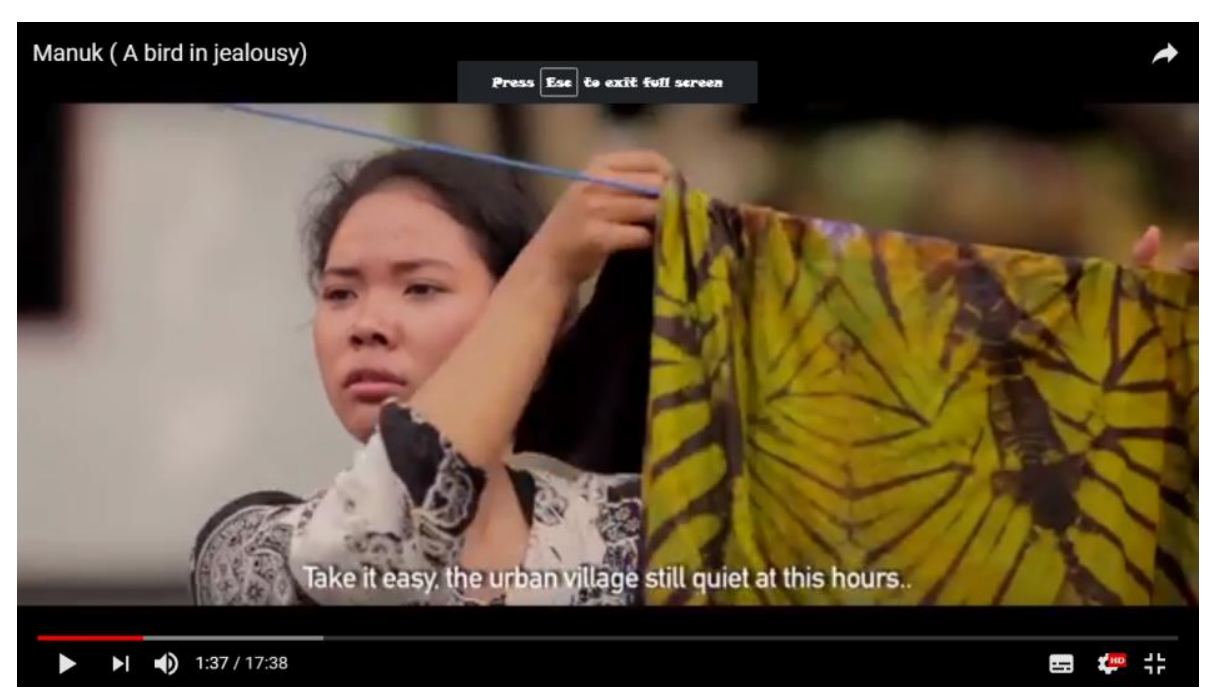

(FM/1:03/1:45)

Kecemasan neurotik yang dialami tokoh utama wanita tersebut dikarenakan sang suami lebih mementingkan burung peliharaanya sedangkan sang istri sudah mengingatkan bahwa sudah suaminya harus segera bekerja. Kecemasan neurotik yang dialami tokoh wanita ini sangat menganggu dan membuat resah tokoh utama wanita yang seolah-olah tidak diperhatikan dan tidak dihiraukan oleh sang suami. Kecemasan neurotik ini muncul seolah-olah individu ini tidak dapat mengatasi lagi kejadian yang ada di hidupnya. Tokoh utama mencoba untuk mengingatkan sang suami, tetapi sang suami tetap tidak menghiraukan perkataan sang istri. Akhirnya, sang istri merasa bahwa perkataanya tidak dihiraukan oleh sang suami sedangkan sang suami malah asyik memperhatikan burung peliharaanya. Dari sinilah muncul kecemasan yang dialami tokoh utama wanita.

Kecemasan yang dialami tokoh utama wanita yaitu kecemasan neurotis. Faktor yang memengaruhi kecemasan neurotik yang ditimbulkan oleh tokoh utama adalah faktor predisposisi. Faktor tersebut adalah konflik emosional yang dialami oleh individu dan tidak terselesaikan dengan baik. Pada diri individu tokoh utama wanita terdapat emosional yang belum terselesaikan. Konflik yang menimbulkan kecemasan pada diri tokoh utama wanita bisa saja berasal dari dalam diri individu ataupun dari lingkungan. Kecemasan pada adegan tersebut adalah kecemasan yang ditimbulkan dari lingkungan yaitu dari sang suami. Hal itu berakibat pada sang istri sudah tidak dapat menoleransi dirinya sehingga menimbulkan kecemasan. 
Pada menit 2:49 sampai dengan menit 3:27 terdapat adegan sang istri pulang dari berbelanja, tetapi sang suami tetap saja belum berangkat ke kantor dan tetap merawat burung peliharaanya dan tidak menghiraukan istri. Sang istri menoleh kepada suami dan suaminya tetap saja merawat burung kesayangannya. Hal itu berakibat pada sang istri merasa dirinya tidak diperhatikan oleh sang suami.

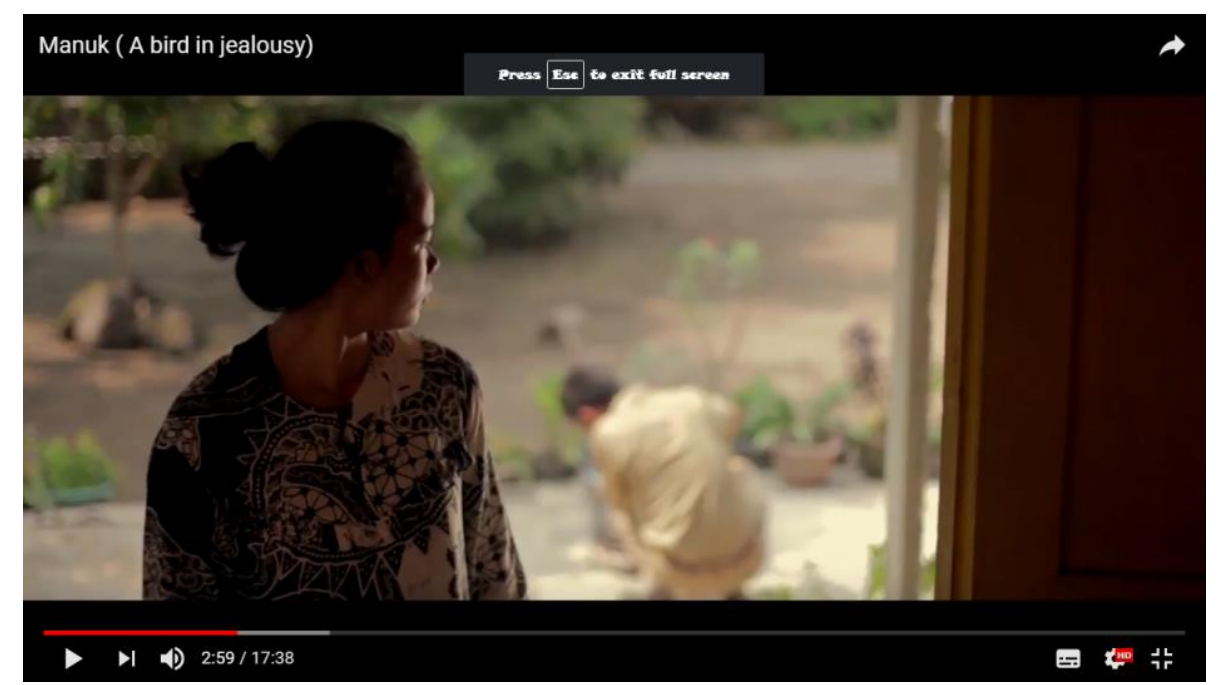

$(\mathrm{FM} / 2: 49 / 3: 27)$

Pada adegan tersebut kecemasan neurotik yang ditimbulkan oleh tokoh utama wanita yaitu saat sang suami belum berangkat kerja padahal sang istri telah selesai berbelanja sehingga timbullah kecemasan. Hal itu membuat tokoh utama wanita berpikir tentang cara agar bisa diperhatikan lagi oleh sang suami. Kecemasan neurotik bisa mengakibatkan seseorang mengambil tindakan yang bisa dikenai hukuman. Kecemasan yang dialami tokoh utama wanita juga termasuk kecemasan neurotik. Kecemasan yang terjadi pada adegan tersebut yaitu saat sang suami tidak menghiraukan perkataan istri. Sejak sebelum berbelanja sampai sang istri telah selesai berbelanja ternyata sang suami tetap belum berangkat kerja sehingga muncullah kecemasan pada diri sang istri.

Kecemasan neurotik muncul jika terdapat ancaman baik fisik maupun hati. Pada adegan tersebut tokoh utama wanita mengalami ancaman hati. Tokoh tersebut merasa tidak diperhatikan dan sang suami sampai rela meninggalkan pekerjaannya hanya demi merawat burung peliharaan kesayangannya. Tokoh utama merasa bahwa keberadaan dirinya sudah tidak dihargai oleh sang suami. Karena itu, tokoh utama wanita mengambil keputusan agar dirinya merasa dihargai dan diperhatikan oleh sang 
suami. Akhirnya, tokoh tersebut bisa memenuhi kebutuhan dirinya karena kebutuhan kasih sayangnya telah dipenuhi oleh sang suami, sedangkan menurut sang istri dirinya tak dihargai lagi karena burung peliharaannya. Berdasarkan adegan tersebut kecemasan tokoh utama wanita memuncak dan akhirnya mengambil tindakan yang nantinya akan dihukum atas perbuatanya. Karena itu, tokoh utama wanita mengambil keputusan untuk mengambil hati sang suami dengan cara yang salah.

Pada menit 3:36 sampai dengan menit 3:50 terdapat adegan sang istri melakukan tes kehamilan di kamar mandi. Sang istri tersebut berencana mengabarkan kehamilan palsu tersebut kepada suami agar sang suami memperhatikan dirinya dan tidak memerhatikan burungnya saja.

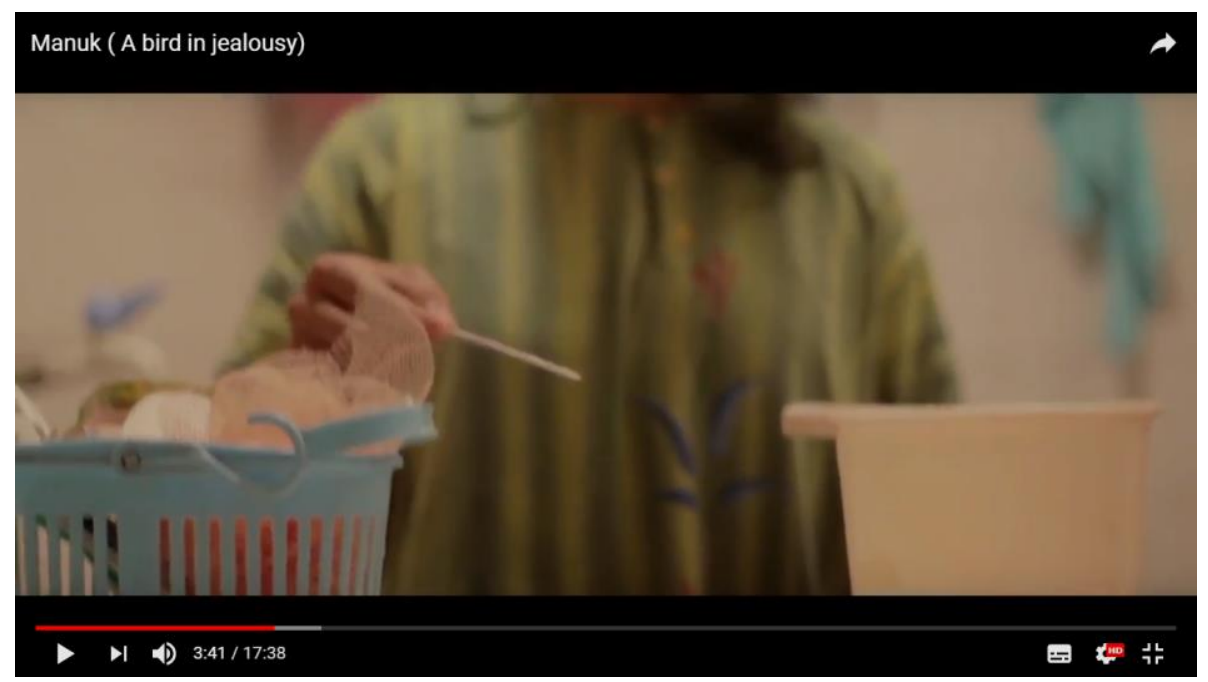

$(\mathrm{FM} / 3: 36 / 3: 50)$

Pada adegan tersebut kecemasan neurotik yang terjadi semakin parah dan sang istri mengambil keputusan untuk mengabarkan bahwa dirinya hamil agar tokoh utama wanita ini mendapatkan perhatian sang suami kembali. Di sisi lain, tokoh tersebut mengetahui bahwa nantinya kabar yang akan diberikan ke suaminya adalah kabar yang tidak benar. Kecemasan neurotik yang pada adegan tersebut menunjukkan bahwa kecemasan yang dialami oleh tokoh utama sudah sangat menyiksa batinnya. Hal itu berakibat pada tokoh utama wanita mengambil keputusan yang nantinya akan memeroleh hukuman akibat dari perbuatannya yang mengaku hamil agar diperhatikan lagi. Hal itu dikarenakan seorang wanita yang sedang hamil membutuhkan perhatian yang lebih. Hal itu berakibat pada tokoh tersebutmengambil keputusan untuk 
mengabarkan kehamilan palsunya agar sang suami lebih memperhatikan dirinya daripada burung peliharaan sang suami.

Tokoh utama wanita telah mengalami kecemasan yang berujung depresi sehingga tokoh tersebut tidak lagi memikirkan benar atau salah keputusan yang telah diambilnya. Tokoh utama wanita sudah tidak mampu mengendalikan dirinya lagi. Hal tersebut sama dengan ciri-ciri pada kecemasan neurotik, yaitu tidak dapat mengendalikan diri terhadap ancaman akan hilangnya status sosial. Pada adegan tersebut sang istri mengalami kehilangan jati diri sebagai istri karena ingin diperhatikan selayaknya istri yang melayani suaminya dengan baik dan mendapatkan perhatian. Dengan cara mengabarkan kehamilan palsunya, sang istri merasa terlindungi dan bisa mengatasi kecemasannya secara sementara karena sang suami sudah tidak terlalu memperhatikan burung peliharaanya. Berdasarkan adegan tersebut tindakan yang dilakukan oleh tokoh utama wanita tepat. Hal itu bertujuan agar tokoh tersebut menemukan identitas diri sehingga dalam dirinya yang mengalami kecemasan neurotik bisa mengambil keputusan yang benar.

Pada menit 6:28 sampai dengan menit 7:21 terdapat adegan sang suami menuruti keinginan istri yang ingin makan duren, ronde, dan berjalan-jalan. Sang istri mengatakan bahwa sudah lama sekali tidak berjalan-jalan dan makan di luar. Sang istri pun tetap protes dikarenakan sang suami yang lebih memerhatikan burung peliharaanya.

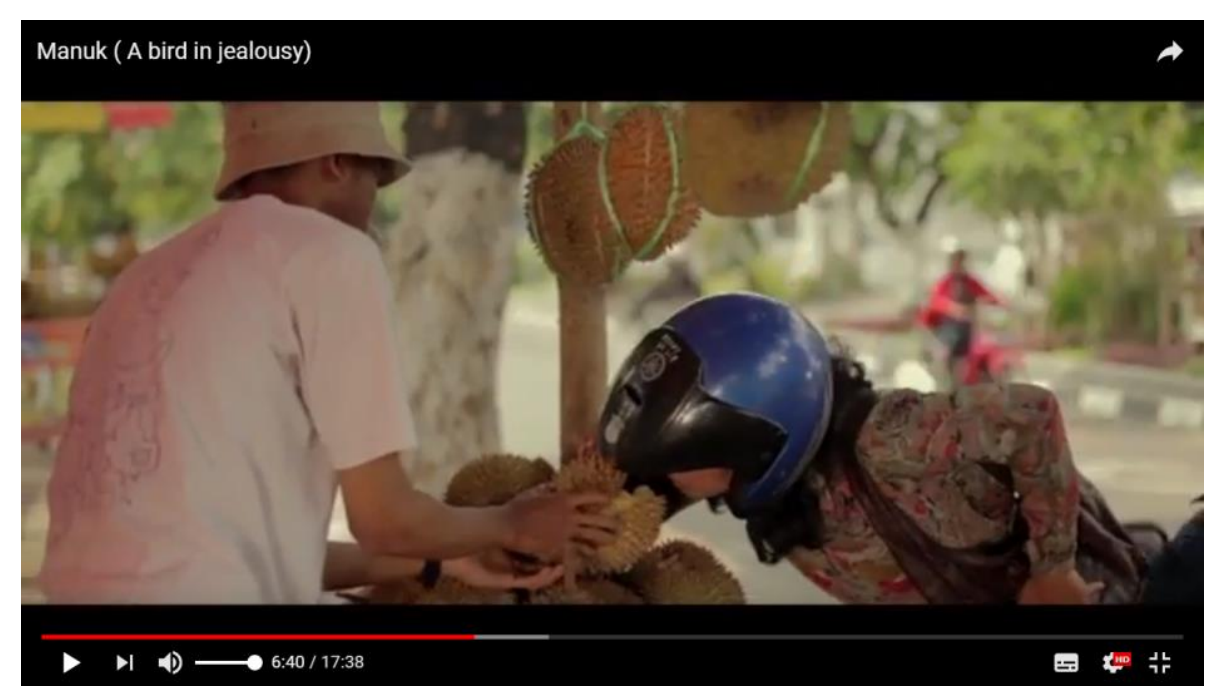

(FM/6:28/7:21) 
Adegan tersebut menandakan adanya kecemasan neurotik dikarenakan tokoh utama wanita memaksa sesuai kehendaknya yaitu ingin berjalan-jalan, makan di luar, dan bersenang-senang dengan sang suami. Sang istri tetap merasa tidak diperhatikan oleh sang suami. Kecemasan neurotik yang dialami sudah dapat diatasi dengan cara mengabarkan kehamilan palsu. Karena itu, sang istri mengajak sang suami untuk berjalan-jalan dan makan di luar untuk memenuhi hasratnya bahwa dirinya telah diperhatikan. Pada awalnya sang suami agak menolak karena merawat burung peliharaanya yang menurut sang istri sangat mengganggu. Akhirnya, sang istri melakukan tindakan yang dapat melindungi dirinya dan menghilangkan kecemasan yang dialaminya. Tindakan yang dilakukan tokoh utama wanita yakni berlaku sewenang-wenang. Tanpa disadari tokoh tersebut telah memaksa sang suami untuk menuruti semua keinginanya.

Faktor yang memengaruhi kecemasan tersebut yaitu faktor presipitasi. Faktor tersebut bermakna ancaman terhadap harga diri baik dari internal maupun eksternal. Faktor itu dapat memengaruhi hubungan yang ada di dalam maupun di luar diri individu. Selain itu, faktor presipitasi juga dapat memengaruhi hubungan yang terjalin sehingga terjadilah hubungan yang baik ataupun buruk dari kecemasan tersebut. Dalam mendapatkan perhatian dari sang suami karena tokoh utama wanita mengalami kecemasan, tokoh tersebut merasa bahwa dirinya sudah tidak dapat diperhatikan lagi maka diambillah sebuah keputusan yang berhasil sehingga sang suami menuruti semua kemauan sang istri.

Pada menit 11:00 sampai dengan menit 12:00 terdapat adegan sang suami sedang merawat burung peliharaannya. Tiba-tiba sang istri keluar dari dalam rumah dan mengatakan bahwa suaminya sudah tidak memperhatikan dirinya lagi dan lebih sayang kepada burung peliharaanya. Karena itu, sang istri yang tengah berpura-pura hamil ini menginginkan burung peliharaan sang suami untuk dijadikan lauk makanan. Sang suami mencoba untuk menolak dan menyarankan untuk membeli lauk yang lain saja, tetapi sang istri menolak dan tetap ingin makan burung peliharaan sang suami. 


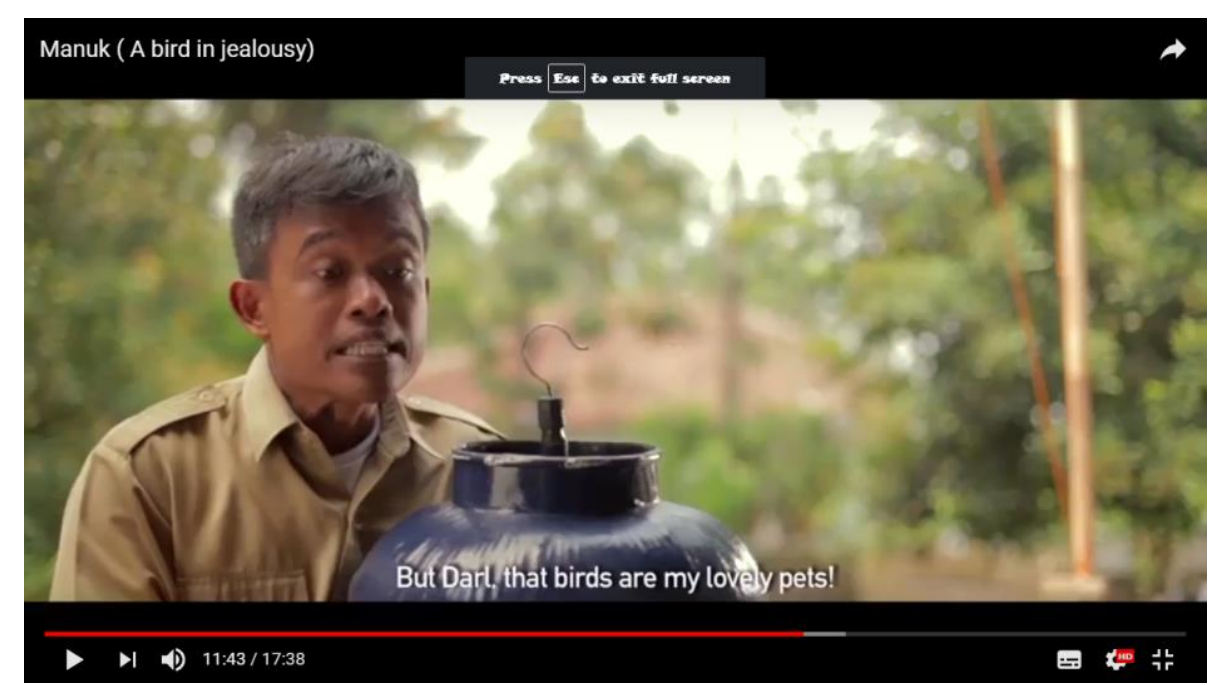

(FM/11:00/12:00)

Pada adegan tersebut tokoh utama wanita merasa tetap tidak dihiraukan. Akhirnya, kecemasan neurotik yang ada di dalam diri tokoh tersebut timbul dan pada saat itu juga tokoh utama wanita itu ingin memakan burung peliharaan suaminya. Tokoh utama wanita mengambil keputusan yang sangat berat. Kecemasan yang dialami tokoh utama wanita sangat membahayakan sehingga tokoh tersebut mengambil keputusan yang dianggap bisa menyelesaikan permasalahan yang sangat mengancam tokoh tersebut. Permintaan tersebut dianggap sang suami sangat berat yaitu sang istri ingin memakan burung peliharaan sang suami. Sang istri beralasan bahwa hal itu dilakukan demi kebaikan anak yang sedang dikandungnya. Dengan alasan tersebut sang istri mudah membujuk sang suami untuk menggoreng burung peliharaannya agar dimakan. Hal itu dilakukan karena sang istri sudah tidak tahan dengan kelakuan sang suami.

Kecemasan neurotik yang dialami oleh tokoh utama wanita (Sum) yang tidak terselesaikan dengan baik bisa menekan rasa amarah dan frustrasi dalam diri tokoh tersebut. Karena itu, Sum melakukan hal-hal yang dianggapnya benar, sehingga Sum tidak bisa berpikir realistis. Keinginan tokoh tersebut akan sulit menjadi kenyataan. Hal tersebut menyebabkan Sum mengalami kecemasan sehingga merugikan orang lain karena ada perbedaan status yang jelas antara Sum sebagai istri dan burung peliharaan suami sebagai hobi pasangan Sum.

Tokoh utama wanita tersebut tidak dapat menangani dunia luar sehingga tidak menyadari bahwa konflik selalu ada di dalam maupun di luar kehidupan. Setiap 
individu memiliki aturan yang harus dipatuhi sehingga siapapun tidak dapat berbuat sewenang-wenang dan tidak merugikan diri maupun orang lain. Tingkah laku yang ditimbulkan oleh tokoh utama mengalami beberapa kali konflik dan tidak terselesaikan sehingga konflik tersebut akan mendatangkan kecemasan. Kebutuhan manusiawi yang tidak bisa dilawan dan tidak terpenuhi juga dapat menimbulkan kecemasan. Burung peliharaan yang dimiliki oleh sang suami inilah yang menyebabkan beberapa konflik yang tidak dapat terselesaikan. Menurut sutradara film Manuk mayoritas orang Jawa memiliki burung peliharaan terutama burung perkutut yang dihadirkan di film ini. Karena itu, burung inilah yang menjadi hobi dan penyebab konflik di antara suami istri.

Pada menit 14:15 sampai dengan menit 15:07 terdapat adegan sang istri mengatakan bahwa dirinya sudah tidak dihargai dan tidak diperhatikan. Hal itu dikarenakan sang suami lebih memperhatikan burung peliharaanya daripada dirinya. Namun, sang suami mengatakan bahwa itu hanya burung peliharaan saja dan tetap rasa sayang dan cintanya pada sang istri.

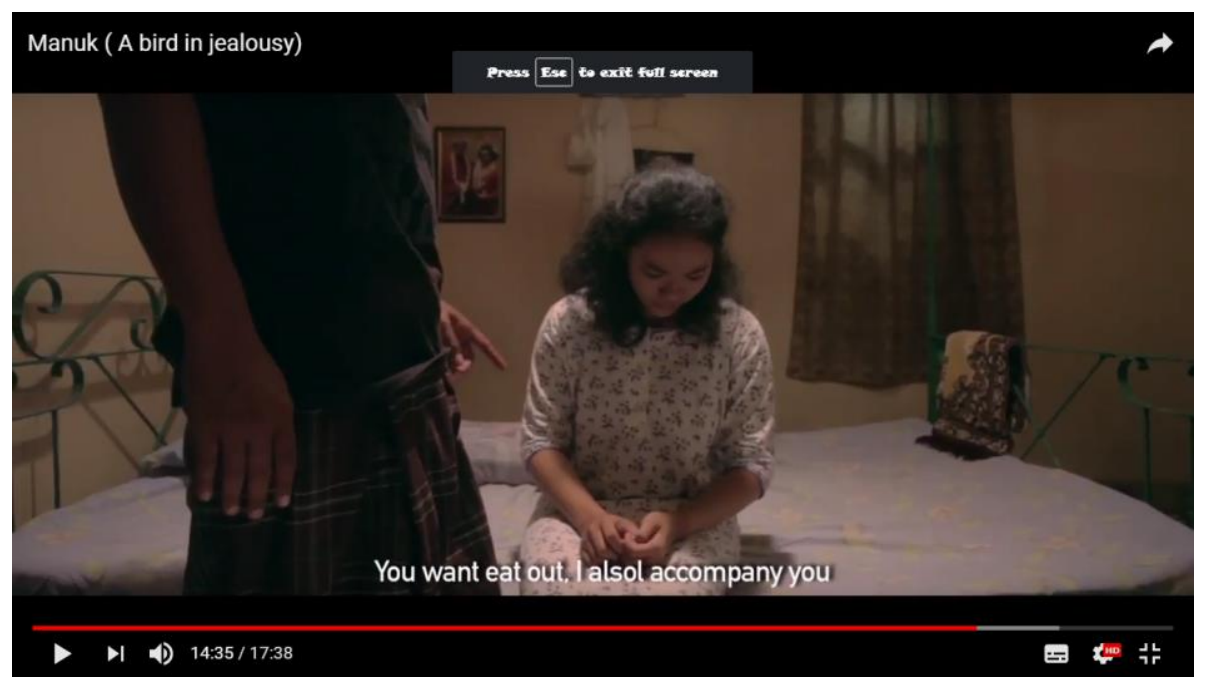

(FM/14:15/15:07)

Kecemasan neurotik bisa muncul karena sang istri merasa bahwa sang suami sudah tidak memperhatikan dan menghargai karena lebih sayang pada burung peliharaannya. Kecemasan neurotik juga dapat disebabkan karena penilaian yang dianggapnya salah. Menurut sang suami, itu hanya burung peliharaan yang tidak dapat menggantikan keberadaan sang istri. Namun, sang istri tetap merasa terganggu 
dengan adanya burung peliharaan kesayangan suaminya. Hal itu berakibat pada sang suami sampai lupa terhadap pekerjaan bahkan kewajibannya sebagai suami.

Kecemasan yang dialami Sum belum tentu dirasakan juga oleh sang suami meskipun sang suami meyakinkan bahwa Sum tetaplah istri yang sangat disayanginya. Jadi, kecemasan yang dialami seorang individu belum tentu individu lain mengalaminya sehingga sang suami merasa baik-baik saja ketika lebih mementingkan burung peliharaanya. Hal itu dikarenakan menurut sang suami itu hanya burung peliharaan yang sampai kapanpun tidak akan bisa menggantikan posisi istri yang disayanginya.

Gangguan kecemasan tersebut adalah gangguan kecemasan pemisah. Jadi, sang istri takut jika sang suami lebih mementingkan burung peliharaannya daripada dirinya. Dari beberapa konflik yang timbul dalam diri Sum maka tokoh tersebut berani berbicara pada sang suami bahwa tokoh tersebut sudah tidak diperhatikan. Sum beranggapan bahwa sang suami lebih memerhatikan burung peliharaannya daripada dirinya.

\section{Kecemasan Moral}

Kecemasan moral adalah rasa takut terhadap suara hati. Misalnya, ketika seseorang merasa bersalah dan belum meminta maaf kepada orang lain, maka orang tersebut akan merasakan kecemasan dan ketakutan sehingga perasaan bersalah ada dalam dirinya. Kecemasan moral ini juga mempunyai dasar dalam realitas. Hal itu dikarenakan pada masa lampau orang telah mendapat hukuman sebagai akibat dari perbuatan yang melanggar kode moral dan mungkin mendapat hukuman lagi (Suryabrata, 2016:139). Berikut kecemasan moral yang terdapat dalam film Manuk.

Tabel 3. Kecemasan Moral dalam Film Manuk

\begin{tabular}{|c|c|c|l|c|c|}
\hline No. & $\begin{array}{c}\text { Menit } \\
\text { Awal }\end{array}$ & $\begin{array}{c}\text { Menit } \\
\text { Akhir }\end{array}$ & \multicolumn{1}{|c|}{ Adegan } & $\begin{array}{c}\text { Jenis } \\
\text { Kecemasan }\end{array}$ & Kode \\
\hline 1. & $13: 05$ & $14: 15$ & $\begin{array}{l}\text { Sang suami akan mengajak } \\
\text { sang istri untuk } \\
\text { memeriksakan } \\
\text { kehamilannya pada bidan, } \\
\text { tetapi sang istri menolak. } \\
\text { Dia beralasan bahwa }\end{array}$ & $\begin{array}{c}\text { Kecemasan } \\
\text { moral }\end{array}$ & FM/13:05/14:15 \\
\hline
\end{tabular}




\begin{tabular}{|l|l|l|l|l|l|}
\hline No. & $\begin{array}{c}\text { Menit } \\
\text { Awal }\end{array}$ & $\begin{array}{c}\text { Menit } \\
\text { Akhir }\end{array}$ & \multicolumn{1}{|c|}{ Adegan } & $\begin{array}{c}\text { Jenis } \\
\text { Kecemasan }\end{array}$ & Kode \\
\hline & & & $\begin{array}{l}\text { kandungan dan dirinya } \\
\text { baik-baik saja, tetapi sang } \\
\text { suami tetap memaksa. }\end{array}$ & & \\
& & & $\begin{array}{l}\text { Akhirnya, sang istri } \\
\text { mengakui bahwa dirinya } \\
\text { tidak hamil. }\end{array}$ & & \\
& & & & & \\
& & &
\end{tabular}

Pada film Manuk, kecemasan moral dibuktikan pada menit 13:05 sampai menit 14:15 terdapat adegan sang suami akan mengajak sang istri untuk memeriksakan kehamilannya pada bidan, tetapi sang istri menolak. Dia beralasan bahwa kandungan dan dirinya baik-baik saja, tetapi sang suami tetap memaksa. Akhirnya, sang istri mengakui bahwa dirinya tidak hamil.

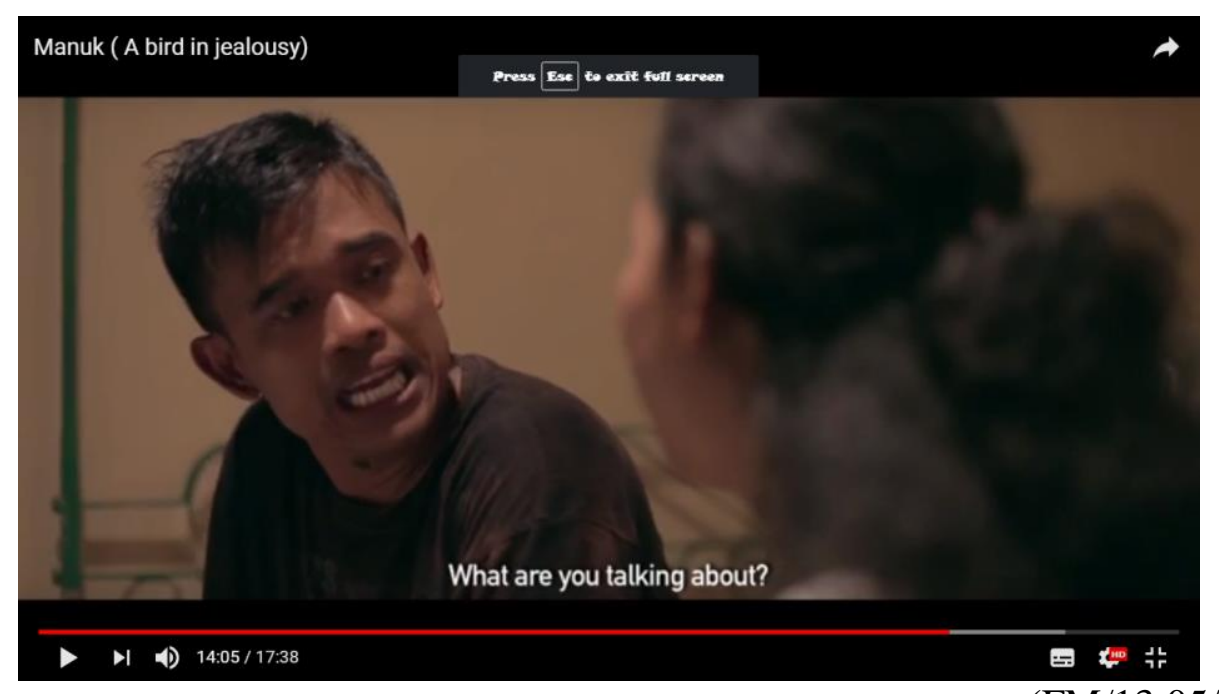

$(\mathrm{FM} / 13: 05 / 14: 15)$

Kecemasan moral memiliki dasar dalam dunia nyata yaitu individu telah mendapatkan hukuman dari perbuatan yang telah dilakukannya. Pada adegan tersebut tokoh utama wanita telah menyadari bahwa dirinya bersalah dan mengakui kesalahannya dan menjelaskan beberapa alasan yang menjadi alasannya untuk berbohong. Sang istri merasa bersalah karena sudah berbohong kepada sang suami sehingga sang suami harus menuruti semua keinginan sang istri. Menurut sang istri itu semua demi kebaikan sang buah hati yang sedang dikandungnya. Merasa bersalah sudah tentu dirasakan oleh tokoh utama wanita. Sum telah berbohong kepada sang suami tentang masalah besar yaitu kehamilannya. Kecemasan moral ini timbul karena 
beberapa kecemasan sehingga individu tersebut merasakan kecemasan dan merasa bersalah atas kejadian yang telah diperbuatnya.

Konflik tersebut menimbulkan kegelisahan dan kecemasan pada diri tokoh utama wanita. Saat Sum telah menyadari bahwa dirinya bersalah atas keputusan yang telah diambil yaitu berbohong kepada sang suami, maka sang istri menyadari dan sang suami coba menjelaskan atas kecemasan sang istri yang selama ini dialami. Sang istri meminta maaf karena telah berbohong kepada sang suami. Kecemasan moral ini adalah kecemasan yang memikirkan perasaan orang lain. Jadi, tokoh utama meminta maaf dan berusaha menjelaskan tentang beberapa konflik batin yang dialaminya. Akhirnya, sang suami meminta maaf atas perbuataanya yang menurut sang istri dia lebih memerhatikan burung peliharaanya.

\section{Id}

Freud mengibaratkan id sebagai raja atau ratu (Minderop, 2011:21). Id berlaku sebagai seperti penguasa absolut, harus dihormati, manja, sewenang-wenang dan mementingkan diri sendiri. Segala hal yang diinginkan harus segera terlaksana.

Pada film Manuk id dibuktikan pada menit 6:13 sampai menit 7:52 dengan adegan sang istri ingin membeli duren, berjalan-jalan, dan makan di luar. Keinginan tersebut harus dituruti hari itu juga dan tidak dapat ditunda oleh sang suami.

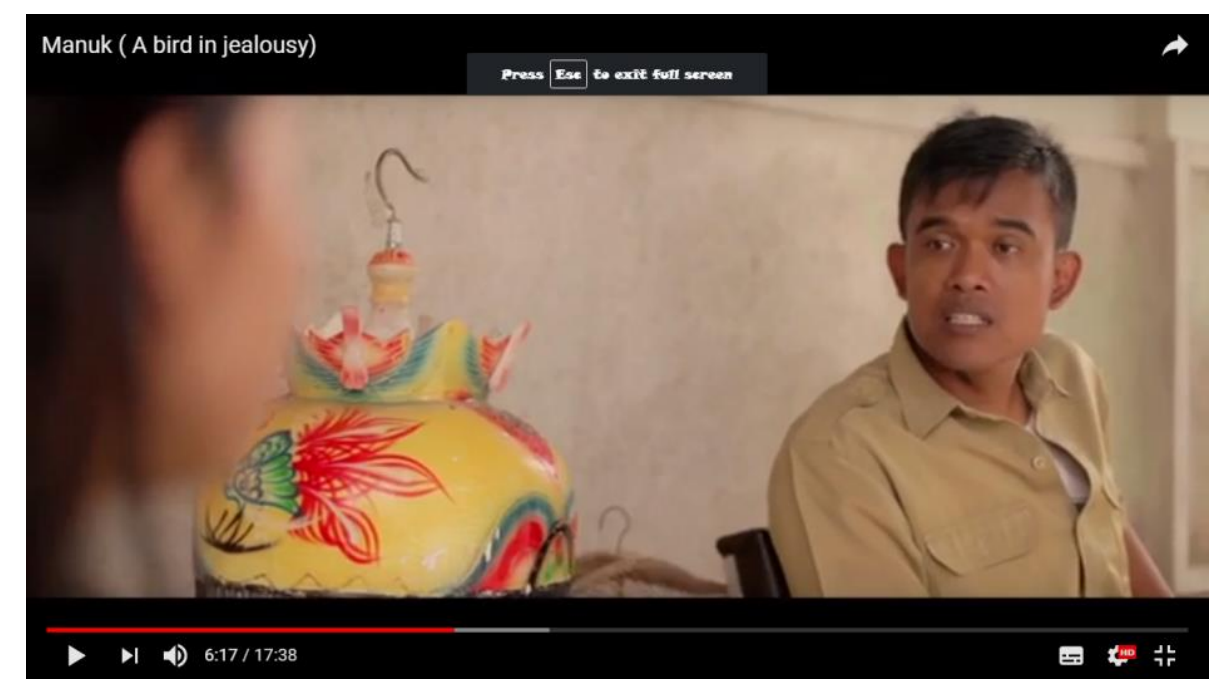

$(\mathrm{FM} / 6: 13 / 7: 52)$

Selain itu, pada menit 8:01 sampai dengan menit 8:50 terdapat adegan sang istri melarang sang suami untuk bekerja. Hal itu dikarenakan dikarenakan sang istri ingin 
kamarnya dihias seperti saat malam pengantin dulu. Keinginan tersebut juga harus dituruti hari itu juga dan tidak dapat ditunda oleh sang suami.

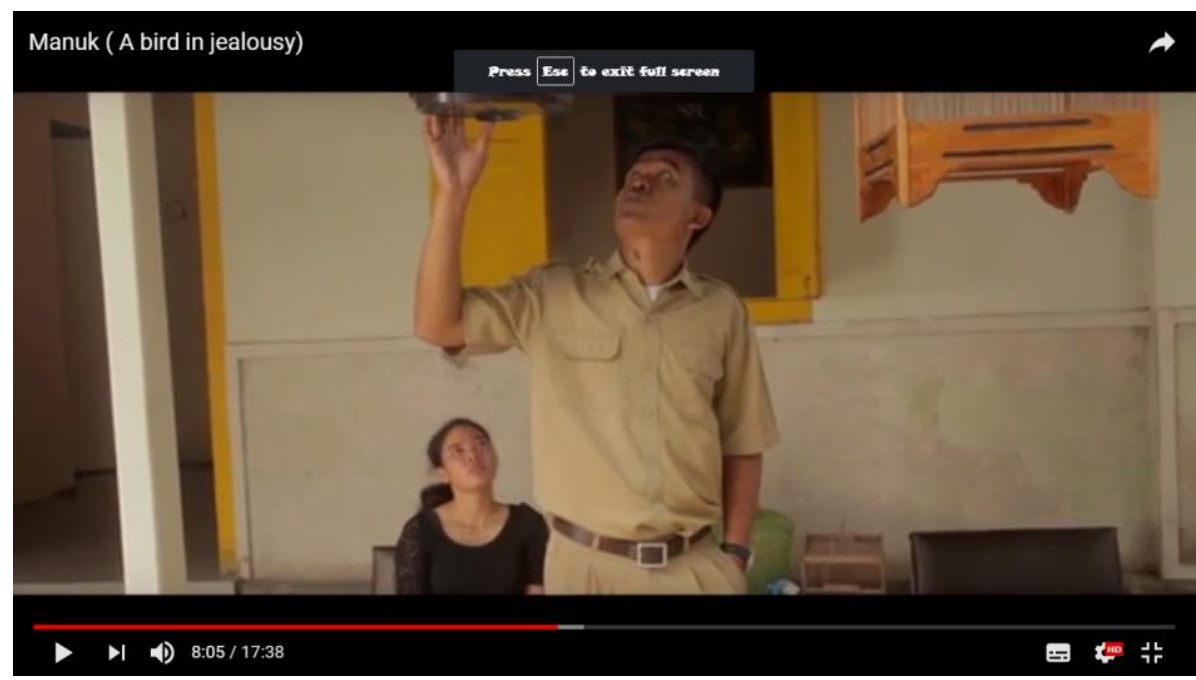

(FM/8:01/8:50)

Pada adegan tersebut sang istri terus memaksa sang suami untuk menuruti semua keinginaanya dan tidak dapat ditunda. Sama halnya dengan id yang bersifat sewenang-wenang. Manusia selalu memiliki kepribadian id, tetapi bergantung pada individu itu untuk mengatasi dan mengantisipasi kepribadian id tersebut.

Pada menit 11:00 sampai dengan menit 12:00 terdapat adegan sang suami sedang merawat burungnya. Tiba-tiba sang istri keluar dari dalam rumah dan mengatakan bahwa suaminya sudah tidak memperhatikan dirinya lagi dan lebih sayang kepada burung peliharaanya. Karena itu, sang istri yang tengah berpura-pura hamil ini menginginkan burung peliharaan sang suami untuk dijadikan lauk makanan. Sang suami mencoba untuk menolak dan menyarankan untuk membeli lauk yang lain saja, tetapi sang istri menolak dan tetap ingin makan burung peliharaan sang suami. 


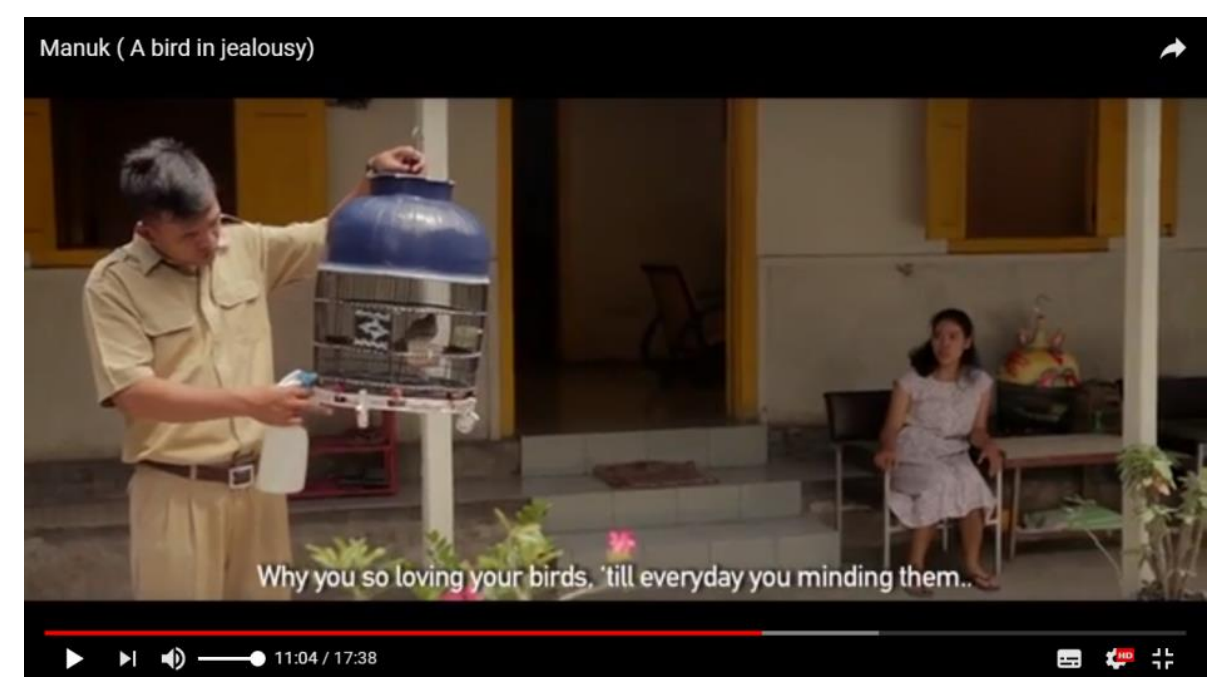

(FM/11:00/12:00)

Pada adegan tersebut sang istri ingin makan burung peliharaan sang suami dikarenakan ingin sekali makan burung tersebut demi anak yang dikandungnya. Sang suami mencoba untuk menjelaskan dan meminta sang istri makan burung dan membeli di luar saja, tetapi sang istri tidak mau dan tetapi ingin makan burung peliharaan sang suami. Dari sinilah kepribadian id tidak mementingkan moral dan tidak memiliki perasaan bahwa yang dilakukannya itu benar atau salah. Kepribadian id ini hanya mementingkan kesenangan saja. Berdasarkan adegan tersebut sang istri ingin makan burung peliharaan sang suami agar sang suami tidak terus-menerus memerhatikan burung peliharaanya saja. Rasa puas dan senang sudah dirasakan saat sang istri telah berhasil membuat sang suami untuk menggoreng burung peliharaanya.

\section{Ego}

Ego diibaratkan sebagai perdana menteri yang memiliki tugas harus menyelesaikan segala pekerjaan yang terhubung dengan realitas dan tanggap terhadap keinginan masyarakat (Minderop, 2011:21).

Ego yang berada di film Manuk ini dapat dibuktikan pada menit 2:28 sampai menit 2:42 dengan adegan tokoh utama wanita atau sang istri yang biasa dipanggil Sum sedang berbelanja bersama tetangganya. Setelah itu datanglah seorang laki-laki yang akan berbelanja dikarenakan istrinya yang sedang hamil. Terlihat tokoh wanita mengalami kecemasan atas pembicaraan tetanggnya megenai kehamilan. 


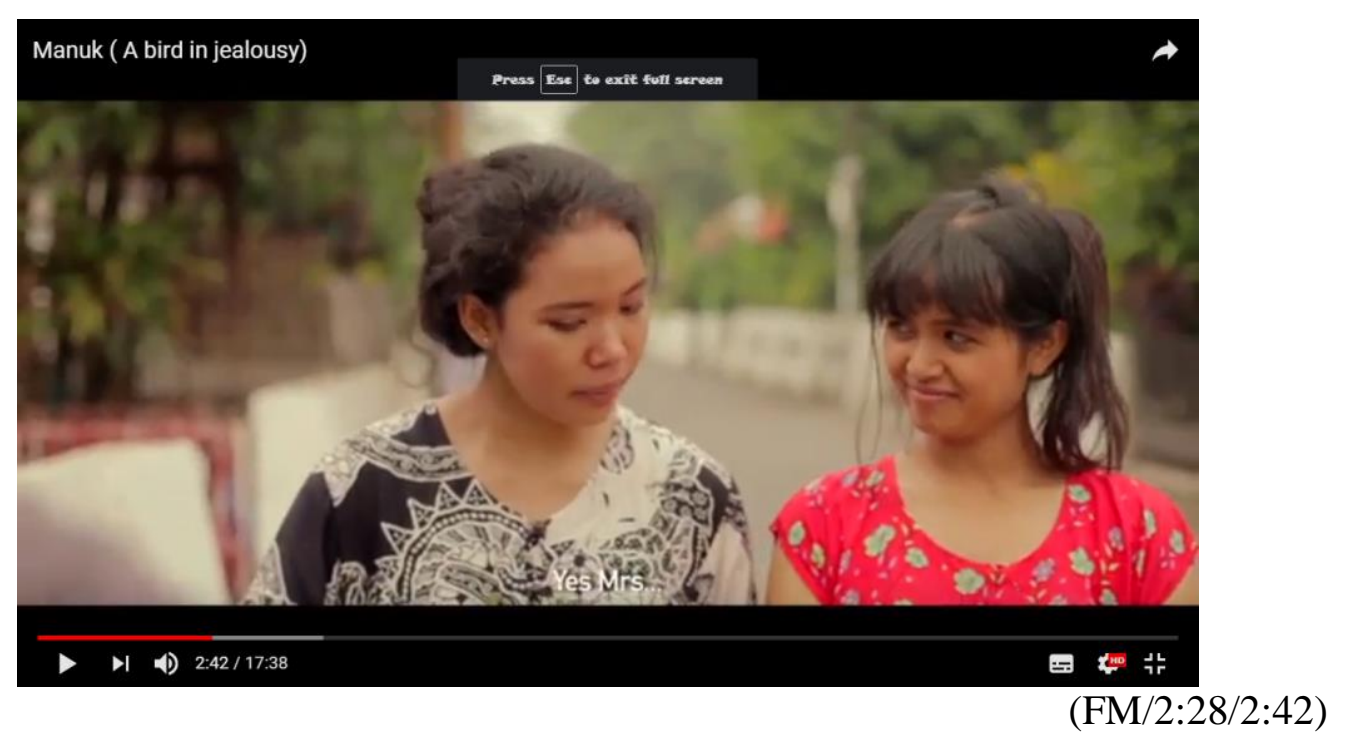

Ego muncul ketika ada keinginan yang berhubungan dengan masyarakat. Berbeda dengan id, ego ini menyelesaikan segala pekerjaan yang terhubung dengan realitas. Kepribadian yang ditimbulkan tokoh utama wanita ini adalah saat para tetangga membicararakan tentang kehamilan maka dia hanya bisa terdiam dan memikirkan tentang kehamilan. Jadi, tokoh tersebut tetap berada di posisi netral yaitu tidak melakukan tindakan apapun saat berbicara dengan tetangganya. Inilah sifat ego yang berada di tengah dan tanggap terhadap keinginan masyarakat sehingga tokoh tersebut memilih diam dan hanya tersenyum saat tetangganya membicarakan tentang kehamilan.

\section{Superego}

Menurut Minderop (2011:21) superego diibaratkan sebagai pendeta yang selalu penuh pertimbangan terhadap nilai-nilai baik dan buruk harus mengingatkan id yang rakus dan serakah bahwa pentingnya perilaku yang arif dan bijak.

Pada film Manuk superego dapat dibuktikan pada menit 14:15 sampai menit 15:07 dengan adegan sang istri mengatakan bahwa dirinya sudah tidak dihargai, tidak diperhatikan, karena sang suami lebih memerhatikan burung peliharaanya daripada dirinya. Namun, sang suami mengatakan bahwa itu hanya burung peliharaan saja dan tetap rasa sayang dan cintanya pada sang istri. 


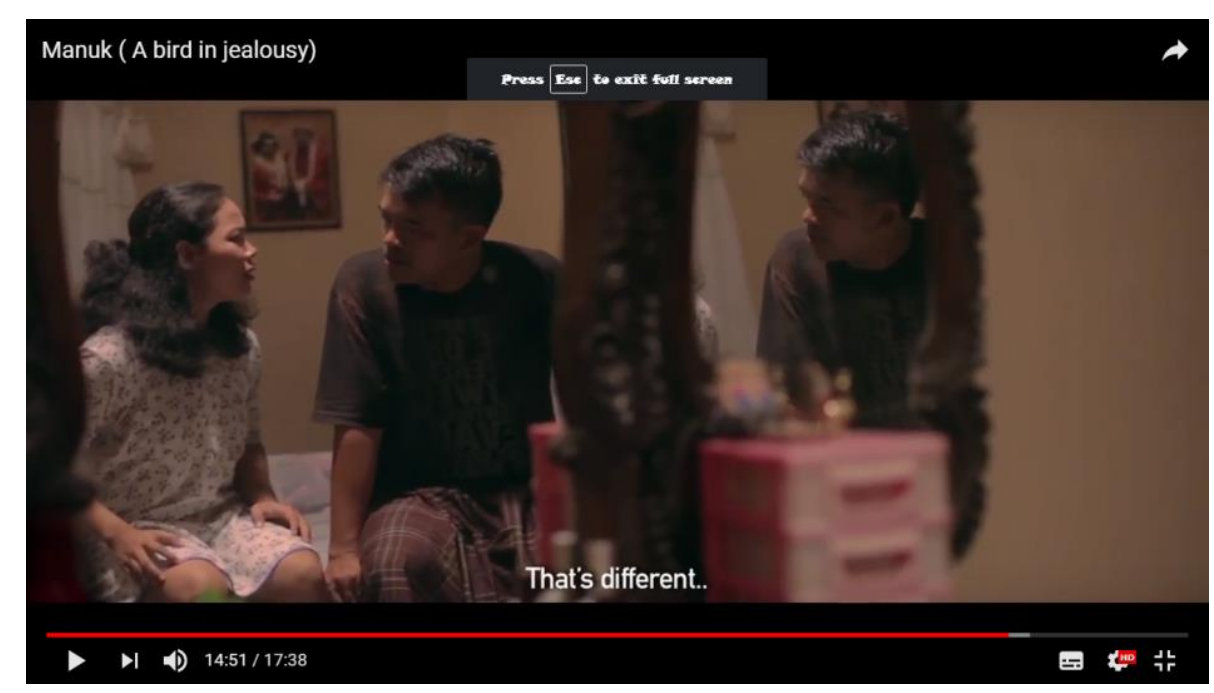

Berdasarkan adegan tersebut sang suami meminta maaf dan sang istri mengakui semua kesalahannya. Selain itu, superego ada pada kepribadiannya dikarenakan superego memiliki pertimbangan nilai baik dan buruk. Jadi, sang suami meminta maaf dan sang istri mengakui segala kesalahan yang telah dilakukannya. Kepribadian superego lebih mementingkan nilai baik dan mengedepankan hati nurani. Karena itu, superego merupakan komponen sosial yang tetap memikirkan orang lain dan tetap menggunakan akal sehat dan hati nurani dalam bertindak.

\section{PENUTUP}

Terdapat satu kecemasan realitas yaitu ditunjukkan pada adegan tokoh utama wanita atau sang istri yang biasa dipanggil Sum sedang berbelanja bersama tetangganya. Setelah itu datanglah seorang laki-laki yang akan berbelanja dikarenakan istrinya sedang hamil. Terlihat tokoh utama wanita mengalami kecemasan atas pembicaraan tetangganya mengenai kehamilan. Kode adegan tersebut adalah $\mathrm{FM} / 2: 28 / 2: 42$.

Terdapat enam kecemasan neurotik yang ditunjukkan pada beberapa adegan yang memiliki kecemasan neurotik. Beberapa adegan kecemasan neurotik ditunjukkan dalam kode FM/1:03/1:45, FM/2:49/3:27, FM/3:36/3:50, FM/6:28/7:21, FM/11:00/12:00, dan FM/14:15/15:07

Terdapat satu kecemasan moral yaitu ditunjukkan pada adegan Sang suami akan mengajak sang istri untuk memeriksakan kehamilannya pada bidan, tetapi sang istri menolak. Dia beralasan bahwa kandungan dan dirinya baik-baik saja, tetapi sang 
suami tetap memaksa. Akhirnya, sang istri mengakui bahwa dirinya tidak hamil. Kode adegan tersebut adalah FM/13:05/14:15.

Dalam kepribadian id terdapat tiga kepribadian id yaitu pada adegan pada menit 6:13 sampai menit 7:52, Selain itu, pada menit 8:01 sampai dengan menit 8:50 dan pada menit 11:00 sampai dengan menit 12:00.

Kepribadian ego dibuktikan pada menit 2:28 sampai menit 2:42 dengan adegan tokoh utama wanita atau sang istri yang biasa dipanggil Sum sedang berbelanja bersama tetangganya. Setelah itu datanglah seorang laki-laki yang akan berbelanja dikarenakan istrinya yang sedang hamil. Terlihat tokoh wanita mengalami kecemasan atas pembicaraan tetanggnya megenai kehamilan.

Kepribadian superego dibuktikan pada menit 14:15 sampai menit 15:07 dengan adegan sang istri mengatakan bahwa dirinya sudah tidak dihargai, tidak diperhatikan, karena sang suami lebih memerhatikan burung peliharaanya daripada dirinya. Namun, sang suami mengatakan bahwa itu hanya burung peliharaan saja dan tetap rasa sayang dan cintanya pada sang istri.

\section{DAFTAR RUJUKAN}

A. King, Laura. 2014. Psikologi Umum Sebuah Pandangan Apresiatif. Jakarta Selatan: Penerbit Salemba Humanika.

A. Pervin, Lawrence., Cervone, Daniel., P. John, Oliver. 2012. Psikologi Teori dan Penelitian. Jakarta: Kencana Prenada Media Grup.

Alwisol. 2014. Psikologi Kepribadian. Malang: UMM Press.

Anggelina Inna, Matilda. 2015. Kepribadian Tokoh Utama Michael Berg dalam Roman Der Vorleser Karya Bernhard Schlink Analisis Psikologi sastra (Skripsi). Yogyakarta: Universitas Negeri Yogyakarta.

Effendy, Heru. 2009. Mari Membuat Film. Jakarta: Penerbit Erlangga.

Fitriyah, Lailatul \& Juhar, Mohammad. 2014. Pengantar Psikologi Umum. Jakarta: Prestasi Pustaka.

Lestari, Titik. 2015. Kumpulan Teori untuk Kajian Pustaka Penelitian Kesehatan. Yogyakarta: Nuha Medika.

Malik, Imam. 2016. Pengantar Psikologi Umum. Yogyakarta: Kalimedia.

Minderop, Albertine. 2011. Psikologi Sastra: Karya Sastra Metode, Teori, dan Contoh Kasus. Jakarta: Yayasan Pustaka Obor Indonesia. 
Pratista, Himawan. 2008. Memahami Film. Yogyakarta: Homerian Pustaka.

Satori, Djama'an \& Komariah, Aan. 2017. Metode Penelitian Kualitatif. Bandung: Penerbit Alfabeta.

Shofiyatun. 2009. Konflik Psikologis Tokoh Utama dalam Novel Tuhan Izinkan Aku Menjadi Pelacur Karya Muhidin M. Dahlan (Skripsi). Semarang: Universitas Negeri Semarang.

Sugiyono. 2015. Metode Penelitian Kualitatif, Kuantitatif, dan R\&D. Bandung: Penerbit Alfabeta.

Suryabrata, Sumadi. 2016. Psikologi Kepribadian. Jakarta: PT RajaGrafindo Persada.

Yuliadi. 2015. Kecemasan Tokoh Utama dalam Novel Layla Majnun Karya Syekh Nizami Ganjavi dan Implikasinya dalam Pembelajaran Sastra di Perguruan Tinggi (Tesis). Lampung: Universitas Lampung

Yusuf, Nurihsan \& Nurihsan, Juntika. 2012. Teori Kepribadian. Bandung: PT Remaja Rosdakarya. 